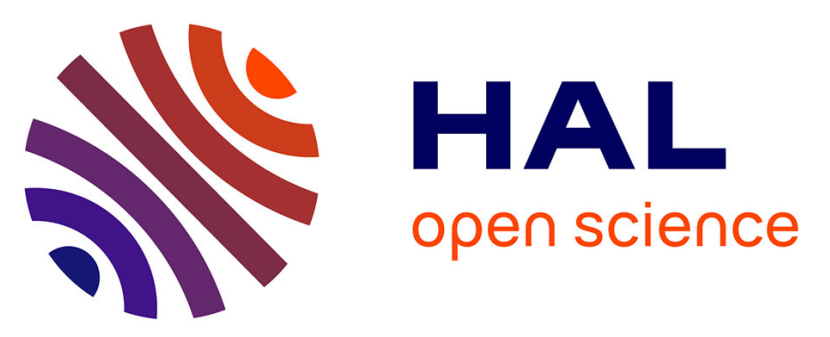

\title{
Vascular endothelial growth factor receptor 2 and downstream p38 mitogen-activated protein kinase are possible candidate markers of intrinsic resistance to adjuvant endocrine treatment in steroid receptor positive breast cancer
}

Barbro K. Linderholm, Henrik Hellborg, Ulla Johansson, Lambert Skoog, Janne Lehtiö

\section{- To cite this version:}

Barbro K. Linderholm, Henrik Hellborg, Ulla Johansson, Lambert Skoog, Janne Lehtiö. Vascular endothelial growth factor receptor 2 and downstream p38 mitogen-activated protein kinase are possible candidate markers of intrinsic resistance to adjuvant endocrine treatment in steroid receptor positive breast cancer. Breast Cancer Research and Treatment, 2010, 125 (2), pp.457-465. 10.1007/s10549010-1252-x . hal-00595942

\author{
HAL Id: hal-00595942 \\ https://hal.science/hal-00595942
}

Submitted on 26 May 2011

HAL is a multi-disciplinary open access archive for the deposit and dissemination of scientific research documents, whether they are published or not. The documents may come from teaching and research institutions in France or abroad, or from public or private research centers.
L'archive ouverte pluridisciplinaire HAL, est destinée au dépôt et à la diffusion de documents scientifiques de niveau recherche, publiés ou non, émanant des établissements d'enseignement et de recherche français ou étrangers, des laboratoires publics ou privés. 
Revised Original article

Vascular endothelial growth factor receptor 2 (VEGFR2) and downstream p38 mitogen activated protein kinase (MAPK) are possible candidate markers of intrinsic resistance to adjuvant endocrine treatment in steroid receptor positive breast cancer

Linderholm Barbro K. ${ }^{1,2}$, Hellborg Henrik ${ }^{3}$, Johansson Ulla ${ }^{3}$, Skoog Lambert ${ }^{4}$ and Lehtiö Janne $^{2}$.

1. Department of Oncology, Sahlgrenska University Hospital, Gothenburg, Sweden

2. Karolinska Biomic Centre (KBC), Karolinska University Hospital, Stockholm

3. Regional Oncologic Centre, Karolinska University Hospital, Stockholm

4. Department of Pathology/Cytology, Karolinska University Hospital, Stockholm

Key words: VEGFR2; p38MAPK; tamoxifen; intrinsic resistance

Address for correspondence:

Barbro K. Linderholm MD, PhD

Department of Oncology

Sahlgrenska University Hospital

SE-413 45 Gothenburg, Sweden

Ph: +46-31-3427941 Fax: +46-31-820114

Email: barbro.linderholm@ki.se 


\section{ABSTRACT}

Purpose: A cross-talk between tyrosine kinase receptors and Mitogen Activated Protein Kinases (MAPK's) is proposed as involved in endocrine resistance. We wanted to investigate intratumoral levels of vascular endothelial growth factor receptor 2 (VEGFR2) and p38 MAPK in relation to relapse-free (RFS) and breast cancer corrected survival (BCCS) in steroid receptor positive patients after adjuvant endocrine treatment, mainly tamoxifen for two or five years. We also wanted to investigate these markers in relation to early and late recurrences. Methods: VEGFR2 $(n=381)$ and p38 $(n=174)$ were determined by enzymelinked immuno-sorbent assays in tumor homogenates from primary BC diagnosed 1993-1996. Results: Wide ranges of VEGFR2 and p38 proteins were found; median $0.72 \mathrm{pg} / \mu \mathrm{g}$ DNA (range 0.0-11.66), and $0.04 \mathrm{pg} / \mu \mathrm{g}$ DNA (range 0.0-6.79) respectively. Detectable levels of p38 were registered in $65 \%$ and classified positive. Higher VEGFR2 were correlated to higher VEGF ( $\mathrm{p}=0.005), \mathrm{p} 38$ MAPK $(\mathrm{p}=0.018)$, negative ER $(\mathrm{p}=0.008)$, larger tumors $(\mathrm{p}=0.001)$, histopathological grade III $(\mathrm{p}=0.018)$, distant metastasis $(\mathrm{p}=0.044)$, shorter RFS $(\mathrm{p}=0.013)$ and shorter BCCS $(\mathrm{p}=0.017)$. Expression of $\mathrm{p} 38$ was significantly correlated with negative $\operatorname{PgR}(\mathrm{p}=0.044)$ and with early relapses $(\mathrm{p}=0.021)$ while no difference was seen during the later follow-up period ( $\mathrm{p}=0.73$ ). Higher VEGFR2 had a significant negative impact on both early $(\mathrm{p}=0.029)$ and later recurrences $(\mathrm{p}=0.018)$ while VEGF only predicted later relapses $(\mathrm{p}=0.037)$. Conclusions: Our preliminary results suggest higher intratumoral levels of VEGFR2 and p38 MAPK as candidate markers of intrinsic resistance for adjuvant endocrine therapy in steroid receptor positive BC. 


\section{INTRODUCTION}

Extracellular stimuli initiated by mitogens, cytokines and growth factors result in aberrations of normal cellular processes as proliferation, differentiation, neo-angiogenesis and invasion, characteristic for cancer growth [1]. This is in part mediated through membrane receptors, such as the receptors tyrosine kinases (RTK's) and downstream mitogen-activated protein kinases (MAPK's) [2]. Increased angiogenesis has been demonstrated to be a significant negative prognostic factor in several solid tumors including breast cancer. Vascular Endothelial Growth Factor (VEGF) is a potent growth factor for endothelial cells that is produced by tumor cells and mediates its effects by binding to VEGF receptors 1-3 (VEGFR1-3) [3]. These receptors are preferably expressed on endothelial cells, although recent data has shown VEGFR2 expression also on the breast cancer cells suggesting existence of an autocrine stimulation in breast cancer progression [4]. Upon ligand binding, VEGFR dimerize and become autophosphorylated resulting in activation of signal transduction cascades including the MAPK's [5]. This is followed by phosphorylation of several cytosolic substrates which translocation to the nucleus, where they activate transcriptional factors resulting in proliferation and migration of endothelial cells into the surrounding stroma. Three MAPK families have been extensively studied; the extracellular regulated kinase (ERK), c-jun amino terminal kinase (JNK) and the high osmolarity glycerol response kinase (p38) [6-7]. Activation of ERK has been attributed to growth factor signaling while JNK and p38 are activated in response to growth factors and by a large spectrum of stress related stimuli [8]. The aim with endocrine therapy is to disrupt estrogen stimulation of breast cancer cells which are mediated via estrogen binding to the estrogen receptor (ER). The expression of steroid receptors is correlated to the benefit of endocrine therapy, with a higher

effect in ER positive patients while the role of $\mathrm{PgR}$ has been debated [9]. Resistance to endocrine therapy has in part been attributed to abnormalities in growth factor signaling. 
Preclinical models of tamoxifen resistance have shown that the steroid receptors not only are functional in response to steroid hormones, but also for multiple signal transduction pathways by a ligand-independent phosphorylation of the ER. Several RTK's i.e., the insulin-like growth factor receptor (IGFR), the epidermal growth factor receptor (EGFR) as well as their downstream cascades has shown to be part of this process [10-11]. Also patients expressing significant levels of ER and/or PgR can have breast cancers that do not respond to endocrine therapy; either at the beginning of treatment (de novo or intrinsic resistance) or after prolonged use (acquired resistance). Data from preclinical model systems investigating initially endocrine sensitive $\mathrm{BC}$ cells subjected to long term anti-estrogen therapy has revealed that there are several stages of acquired resistance with an over-time shift in ER as well as growth factor expression [12]. Patients with acquired resistance might benefit from other types of endocrine intervention as estrogen withdrawal or therapy with the pure antiestrogen fulvestrant [13-14], contrary to patients likely to develop intrinsic resistance, for which endocrine therapy alone should be avoided. Our aim was to investigate intratumoral levels of VEGFR2 and downstream activated p38 MAPK (referred to as p38) in relation to previously determined intratumoral VEGF levels, routine breast cancer factors, localization of relapses and survival in receptor positive patients subjected to adjuvant endocrine treatment. We also wanted to determine if expression of these factors had an impact on early and late relapses. 


\section{PATIENTS AND METHODS}

\section{Patients}

A total of 679 consecutive patients with primary operable invasive breast cancer diagnosed from January $1^{\text {st }} 1993$ through December $31^{\text {st }} 1996$ at two institutions in Stockholm, Sweden had remaining tumor homogenates after determination of steroid receptors in clinical routine. A total of 404 patients with a steroid receptor positive BC subjected to endocrine therapy as only adjuvant systemic treatment have previously been included in a study investigating VEGF in relation to outcome [15]. Patients with remaining preserved tumor homogenates were included in the present study. Patients were identified by use of the Breast Cancer registry data base at the Regional Oncologic Centre, Karolinska University Hospital, Stockholm, Sweden, and are in detail described in previous publications [15-16]. Patients with locally advanced breast cancer, presence of distant metastasis at diagnosis, or those subjected to neoadjuvant therapy were not included.

\section{Tumor tissue preparation}

Representative tumor tissue was cut out and frozen in liquid nitrogen for later analysis of estrogen- and progesterone levels. Frozen tumor tissue was homogenized and suspended in cold standard receptor buffer $(10 \mathrm{mmol} / \mathrm{L}$ Tris $\mathrm{pH}$ 7.4, $1.5 \mathrm{mmol} / \mathrm{L}$ EDTA, $10 \mathrm{mmol} / \mathrm{L}$ sodium molybdate, $1.0 \mathrm{mmol} / \mathrm{L}$ monothioglycerol). Supernatants were collected after refrigerated centrifugation at $20,000 \mathrm{~g}$ and stored at $-70 \mathrm{C}^{\circ}$. The pellet fractions were analyzed for DNA content by the method of Burton, in order to evaluate cell concentrations in samples.

\section{ER and PgR analyses}

ER and PgR content were determined in tumor homogenates by an enzyme immunoassay (Abbott Laboratories, Diagnostic Division, Abbott Park, IL). Receptor concentrations were 
expressed as fmol of receptor per microgram of DNA. The cut-off value used to separate ER or PgR positive from negative was $0.05 \mathrm{fmol}$ receptor/ $\mu \mathrm{g}$ DNA. Steroid receptor levels were used in clinical routine and performed once or twice weekly pending on number of incoming patients samples. The Department of Cytology, Karolinska University Hospital, Stockholm, Sweden participated in the external quality assessment program arranged by the EORTCReceptor and Biomarker Group at the Quality Assessment Laboratory, University Medical Centre Nijmegen, the Netherlands [17].

\section{VEGFR2 analysis}

A VEGFR2 assay was performed by use of a commercial quantitative immunoassay kit for human VEGFR2 (Quantikine, human VEGFR2, R \& D Systems, Minneapolis, MN, USA) according to the manufacturers' recommendations. Tumor homogenates from the primary breast tumor were used. Briefly, a murine monoclonal antibody specific for VEGFR2 had been pre-coated onto a 96-well micro plate. After incubation and washing steps, a secondary polyclonal antibody specific for VEGFR2 was added and used as detection antibody. VEGFR2 levels in patients's samples were expressed as $\mathrm{pg} / \mu \mathrm{g}$ DNA. Analyses of VEGFR2 were performed in a row by one person.

\section{Activated p38 MAPK analysis}

A phospho-p38 MAPK assay was performed by use of a commercial quantitative immunoassay kit for human activated p38 MAPK (Biosource, human phospho-p38 MAPK, Invitrogen, Camarillo, CA, USA) according to the manufacturers' recommendations. Tumor homogenates from the primary breast tumor were used. In summary, a monoclonal antibody specific for p38 MAPK regardless of phosphorylation state had been pre-coated onto a 96well micro plate. After incubation and washing steps, a detection antibody specific for p38 
MAPK phosphorylated at heroine 180 and 182 was added. p38 MAPK protein levels in patients'samples were expressed as $\mathrm{pg} / \mu \mathrm{g}$ DNA. Analyses of $\mathrm{p} 38$ were performed in a row by one person.

\section{Statistical methods}

Pearson chi-square test was used to investigate associations between intratumoral levels of VEGFR2 and p38 MAPK with VEGF as well as routine clinical breast cancer parameters (tumor size, nodal status, histopathological grade, and age). The median levels of VEGFR2 and VEGF in the tumor tissue of all patients $(n=381)$ was used as cut-off point in the statistical analyses, as we wanted to avoid statistically manipulations. Previous publications from our group, as well as other research groups, have analyzed VEGF as a dichotomized variable in relation to survival [18-21]. Patients with detectable levels of p38 were considered positive while those without detectable levels were classified as negative. Kruskal-Wallis test was used to test the null hypothesis of equal VEGFR2 and p38 distributions in samples from the two institutions.

The median follow-up time was defined as the median follow-up for those patients still alive and free from distant recurrences at latest follow-up. Survival was estimated using the Kaplan-Meier method and comparison between study groups was performed with the log-rank test for determination of relapse-free survival (RFS) and breast cancer corrected survival (BCCS), the latter as the majority of deaths were unrelated to breast cancer. Survival analyzes were performed in the total patient population and in the steroid receptor positive group. In order to study the impact of the biomarkers on early and later relapses, the cohort was divided in two strata; patients with early relapses ( $\leq 2$ years of follow-up) and patients with late relapses (after 2 years of follow-up). The reason for choosing 2 year as cut-point was that patients included in the study received endocrine therapy, mainly tamoxifen for two or five 
years. Thereby we were sure that all relapses within the first period occurred early on during adjuvant treatment. Within each group survival was compared between p38 negative versus positive, VEGFR2 negative versus positive and VEGF negative versus positive patients. In order to evaluate the simultaneous effect on different factors on survival, the Cox's proportional hazard model was used. Factors were tested and included in a forward stepwise procedure. For each variable, the patients were classified in two prognostic categories, and the putative best prognosis category was used as the reference. The survival time was measured from date of diagnosis to first documented relapse or death. In all the tests the significance level was set to 0.05 , and all tests were two-sided. The study design is done according to the REMARK criteria for tumor marker studies [22]. 


\section{RESULTS}

\section{Patients characteristics}

Information regarding patients' characteristics was obtained from the Breast Cancer database at the Regional Oncologic Centre, Karolinska University Hospital, Stockholm, Sweden. The database reveals information on all patients with primary breast cancer within the StockholmGotland region. Parameters registered were: date of diagnosis, age, way of detection (mammogram screening or not), type of surgery, tumor size according to the pathologic report, number of removed axillary lymph nodes, number of axillary metastases, and levels of ER and PgR. The database also includes the adjuvant therapy recommended (radiotherapy, adjuvant systemic therapy), date and type of first relapse, date and cause of death. Patients' records were used to collect data on histopathological type and grade and to control that correct data on the adjuvant therapy actually given were registered. Detailed characteristics of the patients are earlier described $[15,16]$. A total of 679 consecutive patients with diagnosis of primary operable breast cancer from 1993 through 1996 at two institutions in Stockholm were identified. Of these, 404 steroid receptor positive patients received endocrine therapy as only systemic adjuvant therapy, mainly tamoxifen for 2 or 5 years (Table 1). VEGF levels in relation to routine $\mathrm{BC}$ biomarkers and stage are previously published [15]. Determination of VEGFR2 and p38 were performed in remaining tumor homogenates in 381 and 174 patients respectively. The endocrine therapy given to the 381 patients with data on VEGFR2 were: tamoxifen 2 years $(n=241)$; tamoxifen 5 years $(n=111)$; GnRH analogue alone or combined with tamoxifen $(n=29)$. Data on clinical stage and routine breast cancer markers are shown in Table 2. The median age of patients included was 63 years (range 29 to 92) and the median follow-up time for patients alive 11.2 years. With this follow-up time a total of 86 recurrences (28 locally, 47 distant and 11 both local and distant) have been registered. The study design was approved by the research ethics board of the Karolinska Institute, Stockholm, Sweden. 


\section{Expression of VEGFR2 and 38 MAPK}

Wide variances in determined levels of VEGFR2 and p38 were found. We did not find any statistically significantly difference in samples from the two participating institutions; MannWhitney U tests VEGFR2 (p=0.59) (Fig 1a) and p38 (p=0.36) (Fig 1b). The median level of VEGFR2 was $0.72 \mathrm{pg} / \mu \mathrm{g}$ DNA (range 0.0-11.66). Higher intratumoral VEGFR2 levels were statistically significant correlated with high VEGF expression $(\mathrm{p}=0.005)$, expression of $\mathrm{p} 38$ MAPK $(\mathrm{p}=0.018)$, negative ER $(\mathrm{p}=0.008)$, larger tumors $(\mathrm{p}=0.001)$, grade III tumors $(\mathrm{p}=0.018)$, premenopausal status $(\mathrm{p}=0.005)$ and distant metastasis $(\mathrm{p}=0.014)$. No correlation was seen between VEGFR2 and PgR status, tumor size, or age (not shown). Detectable levels of p38 were registered in 113 out of 174 patients (65\%) with remaining cytosols for analysis. Expression of p38 was only statistically significant correlated with negative $\operatorname{PgR}(\mathrm{p}=0.044)$.

\section{Survival - univariate analysis}

Higher intratumoral levels of VEGFR2 were statistically significantly correlated with shorter RFS $(\mathrm{HR}=1.9 ; 95 \% \mathrm{CI} 1.1-3.3 ; \mathrm{p}=0.023)$ and $\mathrm{BCCS}(\mathrm{HR}=2.3 ; 95 \% \mathrm{CI}=1.044-5.034, \mathrm{p}=0.039)$. Moreover, high VEGFR2 had a significant impact on survival in both time periods; early relapses, 0-2 years of follow-up $(\mathrm{p}=0.029)$ and later relapses in the subsequent period, > 2 years of follow-up ( $\mathrm{p}=0.018$ ) (Fig $2 \mathrm{a}$ and $\mathrm{b}$ ). High VEGFR2 was associated with an increased risk of relapse $(\mathrm{HR} 1.6 ; 95 \% \mathrm{CI}=0.901-2.913 ; \mathrm{p}=0.107)$ and breast cancer corrected survival (HR 2.4; 95\%CI $=0.955-5.988 ; \mathrm{p}=0.051)$ also in the receptor positive group, however not reaching statistically significance. Expression of p38 was not correlated with survival in the total patient population when studied during the whole follow-up time; RFS ( $\mathrm{p}=0.774$ ) or BCCS ( $\mathrm{p}=0.960$. However, expression of $\mathrm{p} 38$ was significantly correlated to early relapses $(\mathrm{p}=0.021)$ while no difference was seen after 2 years $(\mathrm{p}=0.730)$. The probability of RFS and 
BCCS at 5 years follow-up is shown in Table 3. Contrary, high expression of VEGF was only significantly associated with an increased risk for relapses after 2 years $(p=0.037)$ while no difference was seen in the early follow-up period ( $\mathrm{p}=0.550$ ) (Fig $3 \mathrm{a}$ and $\mathrm{b}$ ). In the group of patients with a $\mathrm{BC}$ positive for both $\mathrm{ER}$ and $\mathrm{PgR}$, p38 remained as a predictor of early relapses $(\mathrm{p}=0.006)$.

Survival - univariate analysis according to earlier determined VEGF and prognostic factors Other factors with statistically significant prognostic value in the total patient population were VEGF; RFS ( $p=0.003), \operatorname{BCCS}(\mathrm{p}=0.002)$. ER status; RFS ( $p=0.002), \operatorname{BCCS}(\mathrm{p}=0.006), \operatorname{PgR}$ status; RFS ( $p=0.008)$, BCCS $(p=0.011)$, tumor size; RFS $(p<0.01)$, BCCS $(p=0.002)$, and nodal status; RFS ( $\mathrm{p}<0.01)$, BCCS $(\mathrm{p}<0.01)$, histological grade; RFS ( $\mathrm{p}=0.001)$, BCCS $(\mathrm{p}=0.007)$ and age $(\mathrm{p}=0.001)$, BCCS $(\mathrm{p}=0.011)$. The same analyses were performed with the steroid receptor negative patients excluded resulting in the corresponding figures; VEGF; (RFS p=0.0177, BCCS p=0.0321) tumor size; RFS ( $\mathrm{p}<0.01)$, BCCS ( $\mathrm{p}=0.009)$, nodal status; RFS ( $p<0.01), \operatorname{BCCS}(\mathrm{p}<0.01)$, histological grade; RFS ( $\mathrm{p}=0.120), \operatorname{BCCS}(\mathrm{p}=0.337)$, and age; $(\mathrm{p}=0.001), \operatorname{BCCS}(\mathrm{p}=0.012)$.

\section{Survival - multivariate analysis}

A Cox proportional hazard regression model was used to estimate hazard ratios (HR) for recurrences and deaths. Analysis was performed in the whole patient population. Due to few events during the early follow-up period analyses were not done separately with patients split in the two follow-up periods. Factors tested were those statistically significantly correlated with survival in univariate analyses. Patient's age was also included. HR above 1.0 indicated a greater risk of recurrence or death than for the comparative group set as reference. VEGFR2 was found as an independent statistically significant factor for RFS (HR=1.8; 95\%CI 1.1 -2.8, 
$\mathrm{p}=0.0016)$ and $\mathrm{BCCS}(\mathrm{HR}=1.8,95 \% \mathrm{CI}=1.1-3.2, \mathrm{p}=0.030)$ respectively. Other factors remaining significantly correlated to RFS were tumor size $(\mathrm{HR}=2.2, \mathrm{p}<0.001)$, nodal status $(H R=2.9, p<0.001), E R(H R=1.9, p=0.016)$ and age $(H R=1.7, p=0.036)$. The same factors were found as independent predictors of $\mathrm{BCCS}$; tumor size $(\mathrm{HR}=1.9, \mathrm{p}<0.001)$, nodal status $(\mathrm{HR}=4.6, \mathrm{p}<0.001), \mathrm{ER}(\mathrm{HR}=1.9, \mathrm{p}=0.049)$ and age $(\mathrm{HR}=3.0, \mathrm{p}=0.001)$ (Table 4). Duration of tamoxifen treatment for 2 years were correlated with an increased risk of relapse; $(\mathrm{HR}=1.4$, $\mathrm{p}=0.306)$, as well as breast cancer corrected survival; $(\mathrm{HR}=2.0, \mathrm{p}=0.122)$, however not reaching statistical significance.

Multivariate analyses were also calculated with the steroid receptor negative patients excluded with minor changes in the results; tumor size (HR 2.1, p=0.01), nodal status (HR 2.7, $\mathrm{p}=0.002)$ and age $(\mathrm{HR} 3.4, \mathrm{p}=0.004)$ remained statistically significant associated with relapsefree survival, while VEGFR2 were not; HR 1.6, p=0.106. For BCCS, nodal status (HR 11.6, $\mathrm{p}<0.01)$ and VEGFR2 (HR 4.2, $\mathrm{p}=0.027)$ remained as independent predictors of breast cancer corrected survival, while tumor size, and age did not. Histological grade did not remain as an independent predictor of RFS or BCCS. 


\section{DISCUSSION}

We investigated the possible effect on survival of VEGFR2 and downstream p38 MAPK in primary breast cancer patients subjected to adjuvant endocrine treatment. The results showed that patients with high intratumoral level of VEGFR2 were more prone to develop distant metastases, and had an impaired survival. A huge amount of publications have shown higher expression of the ligand, VEGF to be correlated with shorter survival times in several tumor types including breast cancer [23]. VEGFR2 is less studied and the data concerning the prognostic and predictive role contradictory. In accordance to our results, a previous study including a large number of premenopausal patients randomized to tamoxifen for two years or no adjuvant endocrine therapy, showed that high VEGFR2 expression were correlated with reduced survival [24]. On the contrary, the same group could not demonstrate that VEGFR2 expression was correlated with survival after adjuvant tamoxifen in ER positive postmenopausal patients [25]. VEGFR2 expression was in both studies determined by immunohistochemistry on tumor micro arrays excluding technical problems solely as explanation for the different results. The latter study on postmenopausal women included fewer patients which in part may contribute to the discrepant results. Variable proportions of patients with Luminal A and B subtypes in pre- and postmenopausal women may also influence the results. In a recent study investigating the correlation between several potential tumor biomarkers and effect of neo-adjuvant chemotherapy, VEGFR2 did not add predictive information for relapse free survival [26].

Examples of pathways involved in intrinsic resistance have been enhanced activity of EGFR or IGFR that result in an impaired estrogen induction of the PgR [10-11, 27]. However, tyrosine kinase receptors have also shown a role in acquired resistance in preclinical studies [28]. How to define patients with intrinsic and acquired resistance respectively is not clear. We hypothesized that candidate markers found at early progress after short-time treatment 
could aid in identification of patients with intrinsic resistance in whom endocrine treatment alone should be avoided up-front. With this aim, we investigated the possible impact of VEGF, VEGFR2 and p38 MAPK on early and later recurrences separately. The time limit was set to two years as all relapses before two years of follow-up occurred when patients still were on treatment.

Intratumoral levels of VEGFR2 had a significant impact on both early and later recurrences. p38 was significantly correlated with an inferior outcome among patients with early relapses also when analyses were restricted to patients with both tumors positive for both ER and PgR. Our findings suggest the VEGFR2-p38 pathway as involved in intrinsic resistance in accordance with previous results in breast cancer cell lines [4, 29]. Expression of p38 was not correlated with later relapses, tumor stage or other breast cancer factors beside negative PgR a marker claimed to be part of intrinsic resistance $[10,11]$. Preclinical studies in ER $\alpha$ expressing endometrial cancer cells have shown multiple functions of p38 of importance in tamoxifen resistance. This includes promotion of ER nuclear localization, enhancement of ER co-activator interaction, as well as, ability to increase the tamoxifen induced estrogen agonistic activity [30]. So far, publications on p38 and other MAPK's in clinical breast cancer populations has been scare with contradictory results. One publication supporting our findings showed that development of tamoxifen resistance during the short time period of neoadjuvant therapy was accomplished by loss of PgR, and an increase in HER2, as well as activated p38 and ERK in some patients [31]. On the contrary, two retrospective clinical studies have shown higher expression of ERK in smaller breast tumors with lower proliferation rate as well as lower incidence of nodal involvement, and a favorable outcome after adjuvant tamoxifen [3233] indicating activation of different intra cellular pathways in endocrine resistance.

The major drawback of the present study is the small patient population, above all regarding p38 analyses, resulting in few events and less power in statistical analyses, unable to fully 
elucidate the role of p38 in endocrine resistance. Technical aspects on p38 should also be discussed. There are four different isoforms out of which p38 $\alpha$ and p38 $\gamma$ have been mostly studied and found to be of pro-apoptotic and proliferative nature, respectively. Since they appear to regulate each other the dominating one will consequently influence which pathway becomes activated [34]. The ELISA we used in our study was not constructed to discriminate between different p38 isoforms as specific antibodies at that time not were available. Our hypothesis is that the dominating isoform we detected might be $\mathrm{p} 38 \gamma$ that induces proliferative pathways, as well as reduce the activation of p38a and thereby also inhibiting its own degradation. Moreover, $\mathrm{p} 38 \gamma$ can contrary to the $\mathrm{p} 38 \alpha$ be activated without phosphorylation, whereby it might be more likely to be preserved also in clinical samples. Despite that our sample size regarding above all p38 MAPK is small and needs to be enlarged and that we lack a randomized patient population, the results may be considered as hypothesis generating. The role of growth factor receptors as well as MAPK's in endocrine resistance deserves to be further studied also after proper treatments periods i.e. five years, in patients subjected to newer endocrine compounds as the aromatase inhibitors, as well as in the molecular sub-types Luminal A and B. 


\section{Declaration of interest:}

None of the authors have any conflict of interest that can be perceived as prejudicing the impartiality of the research reported.

\section{Funding:}

This study was supported by grants from the Swedish Research Council (K2008-54X-2063901-3), the Swedish State under the LUA-agreement (Sahlgrenska University Hospital, Gothenburg) (VGFOUREG-75911), the King Gustav V Jubilee Clinic Cancer Research Foundation, Gothenburg (2009:49), and the Gösta Milton Foundation, Stockholm, Sweden.

Role of the funding sources: The founding sources were not involved in the design of the study, collection, analysis and interpretation of data, nor the writing of the manuscript or the decision to submit the manuscript for publication. 
References

1. Hanahan D, Weinberg R (2000) The hallmarks of cancer. Cell 100:57-70

2. Guo P, Fang Q, Tao HQ, Schafer CA, Fenton BM, Ding I, Hu B, Cheng SY (2003) Overexpression of vascular endothelial growth factor by MCF-7 breast cancer cells promotes estrogen-independent tumor growth in vivo. Cancer Res 63:4684-4691

3. Kroll J, Waltenberger J (1999) A novel function of VEGF receptor-2 (KDR): rapid release of nitric oxide in response to VEGF-A stimulation in endothelial cells. Biochem Biophys Res Commun 265:636-9

4. Aesoy R, Sanchez BC, Norum JH, Lewensohn R, Viktorsson K, Linderholm B (2008) An autocrine VEGF/VEGFR2 and p38 signaling loop confers resistance to 4-hydroxytamoxifen in MCF-7 breast cancer cells. Mol Cancer Res 10:1630-1638

5. Folkman J (2003) Fundamental concepts of the angiogenic process. Curr Mol Med 3:643651. Review.

6. Garrington TP, Johnson GL (1999) Organization and regulation of mitogen-activated protein kinase signaling pathways. Curr Opin Cell Biol 11:211-218. Review

7. Fanger GR (1999) Regulation of the MAPK family members: role of subcellular localization and architectural organization. Histol Histopathol 14:887-894 Review

8. Kyriakis JM, Avruch J (2001) Mammalian Mitogen-activated protein kinase signal transduction pathways activated by stress and inflammation. Physiol Rev 81:807-869 
9. Rutqvist LE, Cedermark B, Fornander T, Glas U, Johansson H, Nordenskjöld B, Rotstein

S, Skoog L, Somell A, Theve T, et al. (1989) The relationship between hormone receptor content and the effect of adjuvant tamoxifen in operable breast cancer. J Clin Oncol 7(10):1474-84

10. Cornier EM, Wolf MF, Jordan VC (1989) Decrease in estradiol-stimulated progesterone receptor production in MCF-7 cells by epidermal growth factor and possible clinical implication for paracrine-regulated breast cancer growth. Cancer Res 49:576-580

11. Cui X, Zhang P, Deng W, Oesterreich S, Lu Y, Mills GB, Lee AV (2003) Insulin-like growth factor-I inhibits progesterone receptor expression in breast cancer cells via the phosphatidylinositol 3-kinase/Akt/mammalian target of rapamycin pathway: progesterone receptor as a potential indicator of growth factor activity in breast cancer. Mol Endocrinol $17: 575-588$

12. Osipo C, Gajdos C, Cheng D, Jordan VC (2005) Reversal of tamoxifen resistant breast cancer by low dose estrogen therapy. J Steroid Biochem Mol Biol 93:249-256

13. Osborne CK, Pippen J, Jones SE, Parker LM, Ellis M, Come S, Gertler SZ, May JT, Burton G, Dimery I, Webster A, Morris C, Elledge R, Buzdar A (2002) Double-blind, randomized trial comparing the efficacy and tolerability of fulvestrant versus anastrozole in postmenopausal women with advanced breast cancer progressing on prior endocrine therapy: results of a North American trial. J Clin Oncol 20:3386-3395 
14. Howell A, Robertson JF, Quaresma Albano J, Aschermannova A, Mauriac L, Kleeberg UR, Vergote I, Erikstein B, Webster A \& Morris C (2002). Fulvestrant, formerly ICI 182,780, is as effective as anastrozole in postmenopausal women with advanced breast cancer progressing after prior endocrine treatment. J Clin Oncol 20:3396-3403

15. Linderholm B, Bergqvist J, Hellborg H, Johansson U, Linderholm M, von Schoultz E, Elmberger G, Skoog L, Bergh J (2009) Shorter survival times following adjuvant endocrine therapy in oestrogen (ER) - and progesterone receptor (PgR) positive breast cancer (BC) overexpressing HER2 and/or with an increased expression of vascular endothelial growth factor (VEGF). Med Oncol 26:480-90

16. Linderholm BK, Hellborg H, Johansson U, Elmberger E, Skoog L, Lehtiö J, Lewensohn R (2009) Significantly higher levels of vascular endothelial growth factor (VEGF) and shorter survival times for patients with primary operable triple negative breast cancer. Ann Oncol 20:1639-1646

17. Geurts-Moespot J, Leake R, Benraad TJ, Sweep CG (2000) Twenty years of experience with the steroid receptor external quality assessment program - the paradigm for tumour biomarker EQA studies. On behalf of the EORTC Receptor and Biomarker Study Group. Int J Oncol 17:13-22 Review 
18. Linderholm B, Tavelin B, Grankvist K, Henriksson R (1998) Vascular Endothelial Growth Factor Is of High Prognostic Value in Node-Negative Breast Carcinoma. J Clin Oncol 16: $3121-3131$

19. Linderholm B, Grankvist K, Wilking N, Johansson M, Tavelin B and Henriksson R (2000) Correlation of Vascular Endothelial Growth Factor (VEGF) and survival, metastasis sites and responsiveness to adjuvant systemic treatment in primary node-positive breast carcinoma. J Clin Oncol 18:1423-1431

20. Foekens JA, Peters HA, Grebenchtchikov N, Look MP, Meijer-van Gelder ME, GeurtsMoespot A, et al. (2001) High tumor levels of vascular endothelial growth factor predict poor response to systemic therapy in advanced breast cancer. Cancer Res 61:5407-5414

21. Manders P, Beex LV, Tjan-Heijnen VC, Span PN, Sweep CG (2003) Vascular endothelial growth factor is associated with the efficacy of endocrine therapy in patients with advanced breast carcinoma. Cancer 98:2125-2132

22. McShane LM, Altman DG, Sauerbrei W, Taube SE, Gion M, Clark GM; Statistics Subcommittee of the NCI-EORTC Working Group on Cancer Diagnostics (2005) Reporting recommendations for tumor marker prognostic studies. J Clin Oncol. 23:9067-9072

23. Poon RT, Fan ST, Wong J (2001) Clinical implications of circulating angiogenic factors in cancer patients. J Clin Oncol 19:1207-1225 
24. Rydén L, Jirström K, Bendahl PO, Fernö M, Nordenskjöld B, Stål O, Thorstenson S, Jönsson PE, Landberg G (2005) Tumor-specific expression of vascular endothelial growth factor receptor 2 but not vascular endothelial growth factor or human epidermal growth factor receptor 2 is associated with impaired response to adjuvant tamoxifen in premenopausal breast cancer. J Clin Oncol 23:4695-4704

25. Rydén L, Stendahl M, Jonsson H, Emdin S, Bengtsson NO, Landberg G (2005) Tumorspecific VEGF-A and VEGFR2 in postmenopausal breast cancer patients with long-term follow-up. Implication of a link between VEGF pathway and tamoxifen response. Breast Cancer Res Treat 89:135-143

26. Guarneri V, Piacentini F, Ficarra G, Frassoldati A, D'Amico R, Giovannelli S, Maiorana A, Jovic G, Conte P (2009) A prognostic model based on nodal status and Ki-67 predicts the risk of recurrence and death in breast cancer patients with residual disease after preoperative chemotherapy. Ann Oncol 20:1193-1198

27. Johnston SR, Saccani-Jotti G, Smith IE, Salter J, Newby J, Coppen M, Ebbs SR, Dowsett M (1995) Changes in estrogen receptor, progesterone receptor, and pS2 expression in tamoxifen-resistant human breast cancer. Cancer Res 55:3331-3338

28. Knowlden JM, Hutcheson IR, Jones HE, Madden T, Gee JM, Harper ME, Barrow D, Wakeling AE, Nicholson RI (2003) Elevated levels of epidermal growth factor receptor/cerbB2 heterodimers mediate an autocrine growth regulatory pathway in tamoxifen-resistant MCF-7 cells. Endocrinology 144:1032-1044 
29. Bunone G, Briand PA, Miksicek RJ, Picard D (1996) Activation of the unliganded estrogen receptor by EGF involves the MAP kinase pathway and direct phosphorylation. EMBO J 15 2174-2183

30. Lee H and Bai W (2002) Regulation of estrogen receptor nuclear export by ligand-induced and p38-mediated receptor phosphorylation. Mol Cell Biol 22:5835-5845

31. Gutierrez MC, Detre S, Johnston S, Mohsin SK, Shou J, Allred DC, Schiff R, Osborne CK \& Dowsett M 2005 Molecular changes in tamoxifen-resistant breast cancer: relationship between estrogen receptor, HER-2, and p38 mitogen-activated protein kinase. J Clin Oncol $23: 2469-2476$

32. Svensson S, Jirström K, Rydén L, Roos G, Emdin S, Ostrowski MC, Landberg G (2005) ERK phosphorylation is linked to VEGFR2 expression and Ets-2 phosphorylation in breast cancer and is associated with tamoxifen treatment resistance and small tumours with good prognosis. Oncogene 24:4370-4379

33. Bergqvist J, Elmberger G, Odh J, Linderholm B, Bjohle J, Hellborg H, Nordgren H, Borg AL, Skoog L, Bergh J (2006) Activated ERK1/2 and phosphorylated oestrogen receptor alpha are associated with improved breast cancer survival in women treated with tamoxifen. Eur J Cancer 42:1104-1112 
34. Qi X, Pohl NM, Loesch M, Hou S, Li R, Qin JZ, Cuenda A, Chen G (2007) p38alpha antagonizes p38gamma activity through c-Jun-dependent ubiquitin-proteasome pathways in regulating Ras transformation and stress response. J Biol Chem 282:31398-31408 
Legends to Figures

Fig $1 \mathrm{a}$ and b Mann-Whitney U tests comparing levels of VEGFR2 (p=0.59) (Fig 1a) and p38 $(\mathrm{p}=0.36)($ Fig $1 \mathrm{~b})$ between the two participating institutions

Fig 2a Early Recurrences (0-2 years follow-up) according to intratumoral levels of VEGFR2 $(\mathrm{p}=0.029)$ in steroid receptor positive breast cancer subjected to adjuvant tamoxifen

Fig 2b Late Recurrences (after 2 years follow-up) according to intratumoral levels of VEGFR2 ( $\mathrm{p}=0.018)$ in steroid receptor positive breast cancer subjected to adjuvant tamoxifen

Fig 3a Early Recurrences (0-2 years follow-up) according to intratumoral levels of VEGF $(p=0.55)$ in steroid receptor positive breast cancer subjected to adjuvant tamoxifen Fig 3b Late Recurrences (after 2 years follow-up) according to intratumoral levels of VEGF $(\mathrm{p}=0.037)$ in steroid receptor positive breast cancer subjected to adjuvant tamoxifen 
Table 1. REMARK diagram showing how patients included in the study were selected

$\downarrow$

679 patients

with primary operable $\mathrm{BC}$ and remaining cytosols after determination of steroid receptors within clinical routine

Endocrine therapy only $\quad 409$

Chemotherapy only 41

Both chemo- and endocrine therapy $\quad 48$

No systemic adjuvant therapy $\quad 181$

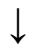

404 patients

ER and/or PgR positive receiving adjuvant endocrine therapy as only systemic therapy with previously determined VEGF

$\downarrow$

381 patients

with remaining cytosols for VEGFR2

$\downarrow$

174 patients

with remaining cytosols for $\mathrm{p} 38 \mathrm{MAPK}$ 
Table 2. Clinicopathological data of steroid receptor positive patients receiving adju vant endocrine therapy with data on VEGF $(n=404)$, VEGFR2 $(n=381)$ and p38 $(n=174)$.

\begin{tabular}{lllc}
\hline Feature & $\begin{array}{l}\text { VEGF } \\
\text { number }(\%)\end{array}$ & $\begin{array}{l}\text { VEGFR2 } \\
\text { number }(\%)\end{array}$ & $\begin{array}{l}\text { p38 } \\
\text { number }(\%)\end{array}$ \\
\hline $\begin{array}{l}\text { Patients enrolled } \\
\text { Tumor size }\end{array}$ & 404 & 381 & 174 \\
Median & & & $14 \mathrm{~mm}$ \\
T1 & $15 \mathrm{~mm}$ & $15 \mathrm{~mm}$ & $128(74 \%)$ \\
T2 & $289(72 \%)$ & $274(72 \%)$ & $44(25 \%)$ \\
T3 & $107(26 \%)$ & $101(26 \%)$ & $2(1 \%)$ \\
\end{tabular}

\section{Lymph-node status}

Node-negative

$292(72 \%)$

$276(72 \%)$

$123(71 \%)$

Node-positive

$87(22 \%)$

$83(22 \%)$

$37(21 \%)$

Unknown

$25(6 \%)$

$22(6 \%)$

$14(8 \%)$

\section{Histological grade}

I+II

III

Not analyzed

$E R^{*}$

neg

pos

$\operatorname{PgR}$ *

pos

neg

HER2 positive
$180(44 \%)$

$126(31 \%)$

$98(25 \%)$

$58(14 \%)$

$346(86 \%)$

$306(76 \%)$

$98(24 \%)$

$45(11 \%)$
$156(41 \%)$

$75(43 \%)$

$137(36 \%)$

$57(33 \%)$

$88(23 \%)$

$42(24 \%)$

$29(17 \%)$

$145(83 \%)$

$329(86 \%)$

$289(76 \%)$

$129(74 \%)$

$91(24 \%)$

$45(26 \%)$

$40(10 \%)$
$17(10 \%)$

* ER $=$ Estrogen Receptor, $\mathrm{PgR}=$ Progesterone Receptor, pos $(\geq 0.05 \mathrm{fmol} / \mu \mathrm{g}$ DNA $)$, neg $(<0.05 \mathrm{fmol} / \mu \mathrm{g}$ DNA $)$ 
Table 3. Probability of recurrence-free (RFS) and breast cancer corrected survival (BCCS) according to VEGFR2 and p38 MAPK at 5 years follow-up

\section{Recurrence-free survival (RFS) in all patients}

variable 5year surv $88 \% \mathrm{CI} \quad \mathrm{HR} \quad 95 \% \mathrm{CI}$ p-value

\section{VEGFR2}

$\begin{array}{lrrrrr}0 & 91.3 \% & 87-95 \% & & & \\ 1 & 82.3 \% & 77-88 \% & 1.9 & 1.1-3.3 & 0.022 \\ & & & & & \\ \text { p38MAPK } & & & & & \\ 0 & 86.5 \% & 77-95 \% & & & \\ 1 & 90.5 \% & 85-96 \% & 0.9 & 0.4-2.8 & 0.823\end{array}$

\section{Breast cancer corrected survival (BCCS) in all patients}

variable 5year surv $88 \% \mathrm{CI} \quad \mathrm{HR} \quad 95 \% \mathrm{CI} \quad$ p-value

VEGFR2

$\begin{array}{llllll}0 & 95.6 \% & 93-99 \% & & & \\ 1 & 91.1 \% & 87-95 \% & 2.3 & 1.05-5.6 & 0.038 \\ & & & & & \\ \text { p38MAPK } & & & & & \\ 0 & 94.8 \% & 89-100 \% & & & \\ 1 & 94.4 \% & 90-99 \% & 1.5 & 0.4-5.65 & 0.550\end{array}$


Table 4. Factors remaining statistically significant in Cox multivariate analysis for recurrencefree survival (RFS) and breast cancer corrected survival (BCCS) in the total patient population regardless of time for relapse. ${ }^{*} 95 \%$ Confidence Interval

Variable

Hazard Ratio (HR)

$95 \% \mathrm{CI}^{*} \quad$ p-value

\section{RFS}

Nodal status

Negative

Not known

1.0

Positive

1.9

2.9

0.8-4.5

0.123

1.9-4.6

$<0.001$

Tumor size

$<20 \mathrm{~mm}$

1.0

20-50 mm

2.2

$1.4-3.3<0.001$

VEGFR2

$<$ median

1.0

Not known

2.7

$\geq$ median

1.8

1.3-5.8

0.011

$\mathrm{ER}^{\S}$

Positive

1.0

Negative

1.9

1.1-3.2 $\quad 0.021$

Age

$<$ median

1.0

$\geq$ median

1.7

$1.0-2.7 \quad 0.036$

Grade

1-2

1.0

Not known

1.2

$1.1-2.8 \quad 0.016$

$3+$

1.5

0.6-2.6 $\quad 0.639$

$1.0-2.3 \quad 0.069$ 


\section{BCCS}

Nodal status

Negative

1.0

Not known $\quad 3.7$

Positive

4.6

$1.5-9.2$

0.005

Tumor size

$<20 \mathrm{~mm}$

20-50 mm

1.0

1.9

1.2-3.2 $\quad 0.011$

\section{VEGFR2}

$<$ median

1.0

Not known $\quad 3.0$

$\geq$ median

1.8

1.2-7.4

$1.1-3.2 \quad 0.030$

$\mathrm{ER}^{\S}$

Positive

1.0

Negative

1.9

$1.0-3.8 \quad 0.049$

Age

$$
<\text { median }
$$

1.0

$\geq$ median

3.0

1.5-5.8 $\quad 0.001$

Grade

$\begin{array}{llll}1-2 & 1.0 & & \\ \text { Not known } & 0.9 & 0.3-2.6 & 0.851 \\ 3+ & 1.3 & 0.8-2.1 & 0.380\end{array}$

$\S \mathrm{ER}=$ Estrogen Receptor, pos $(\geq 0.05 \mathrm{fmol} / \mu \mathrm{g} \mathrm{DNA})$, neg $(<0.05 \mathrm{fmol} / \mu \mathrm{g} \mathrm{DNA})$. 

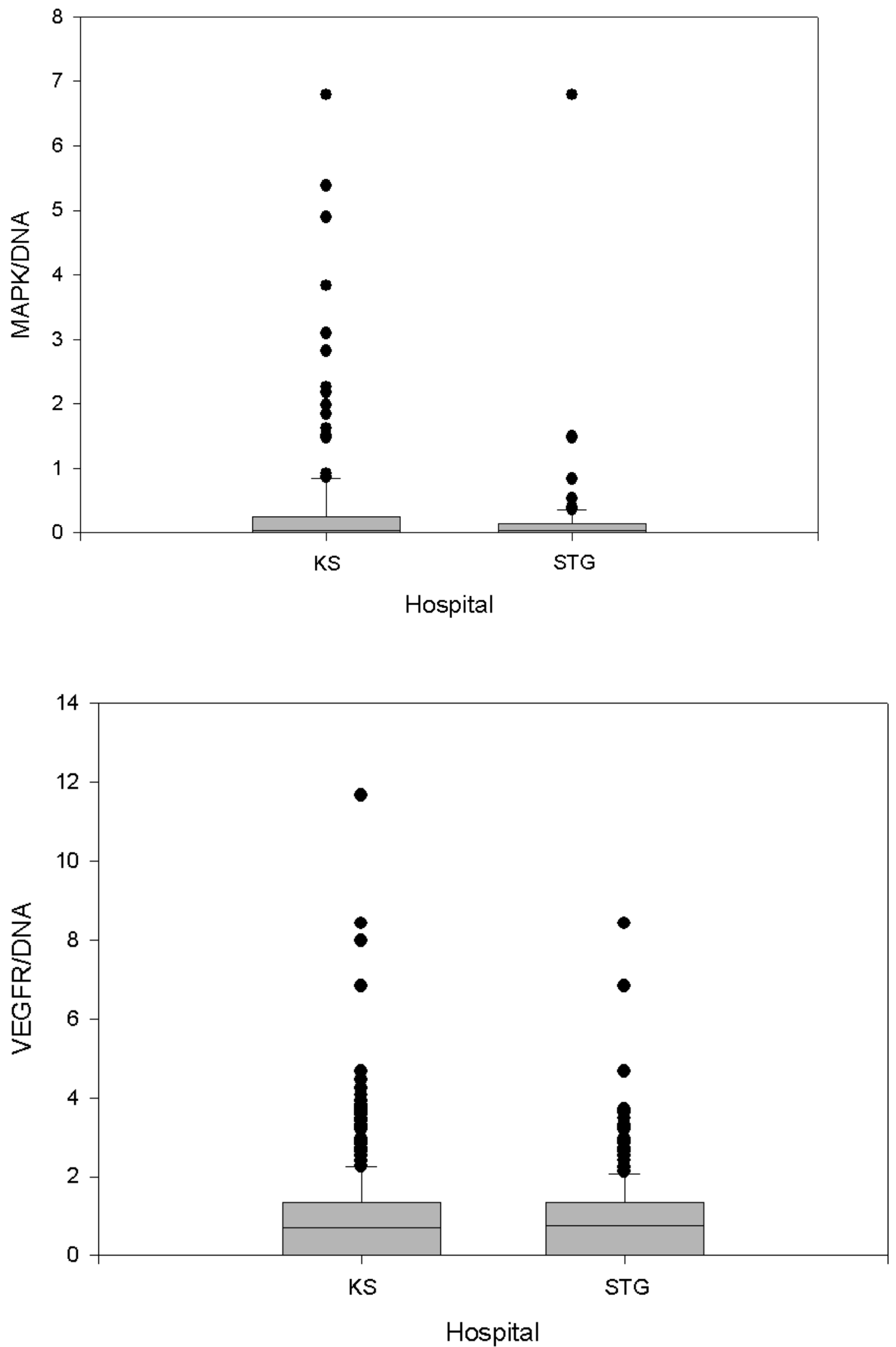


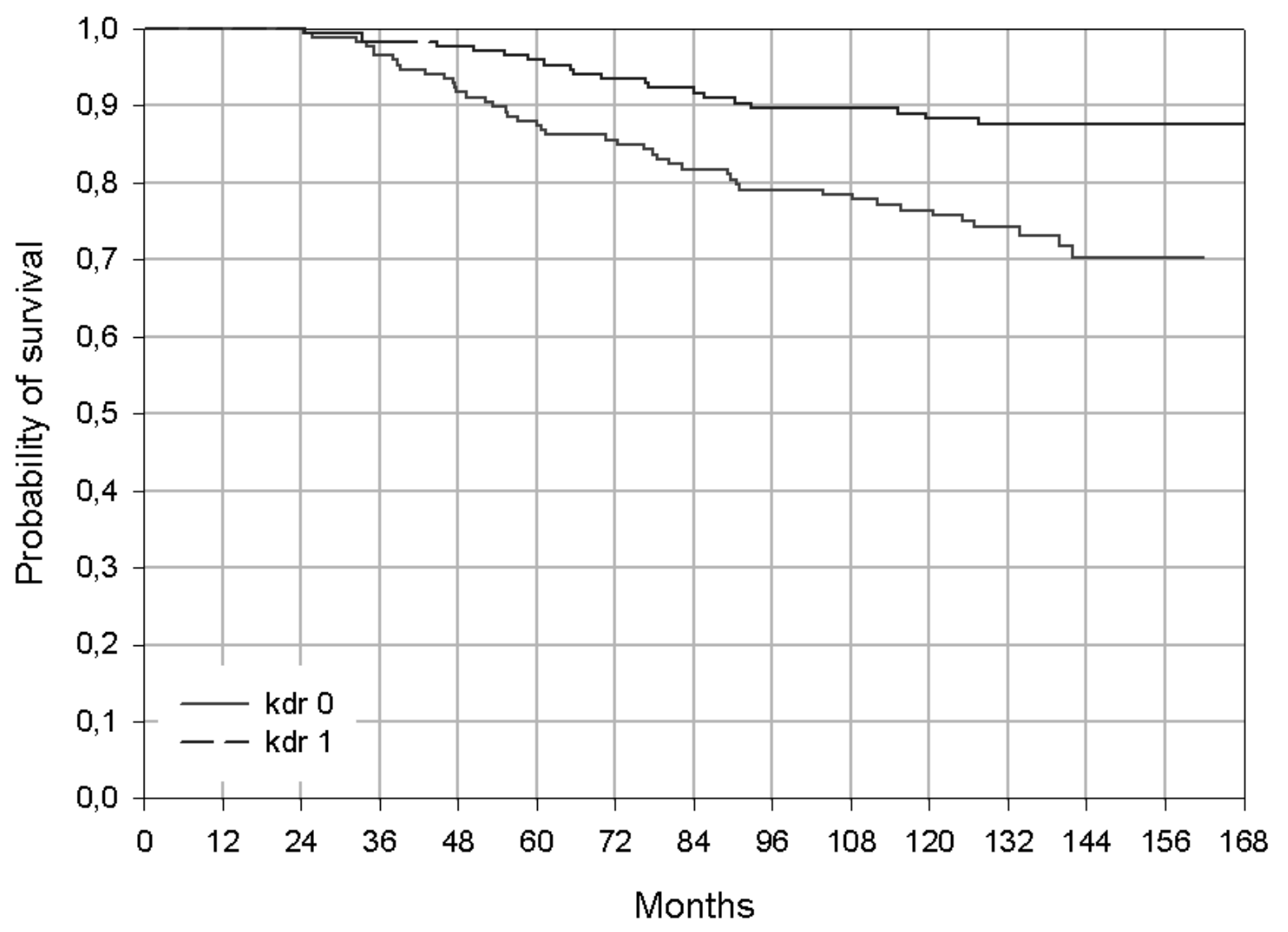




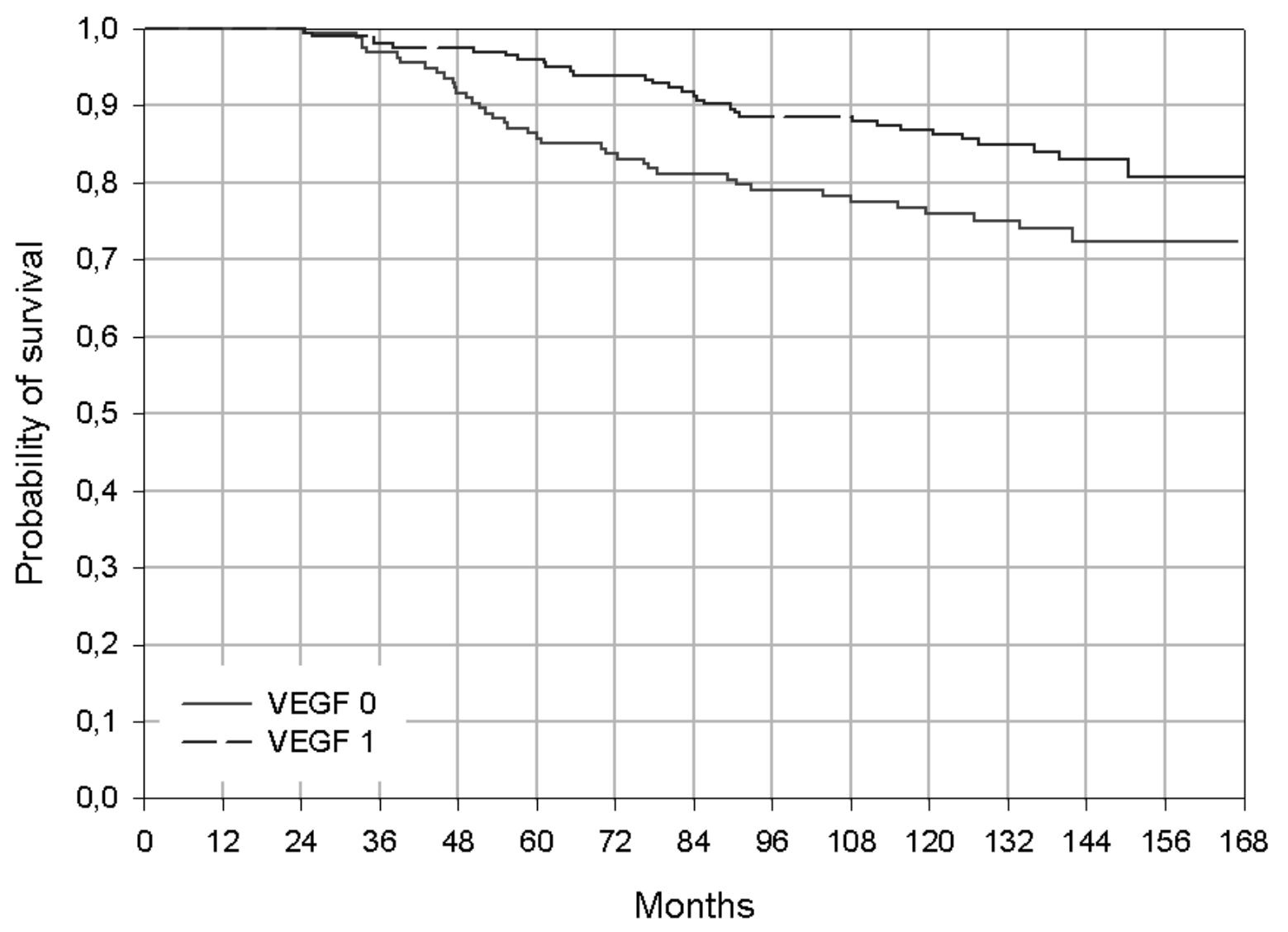




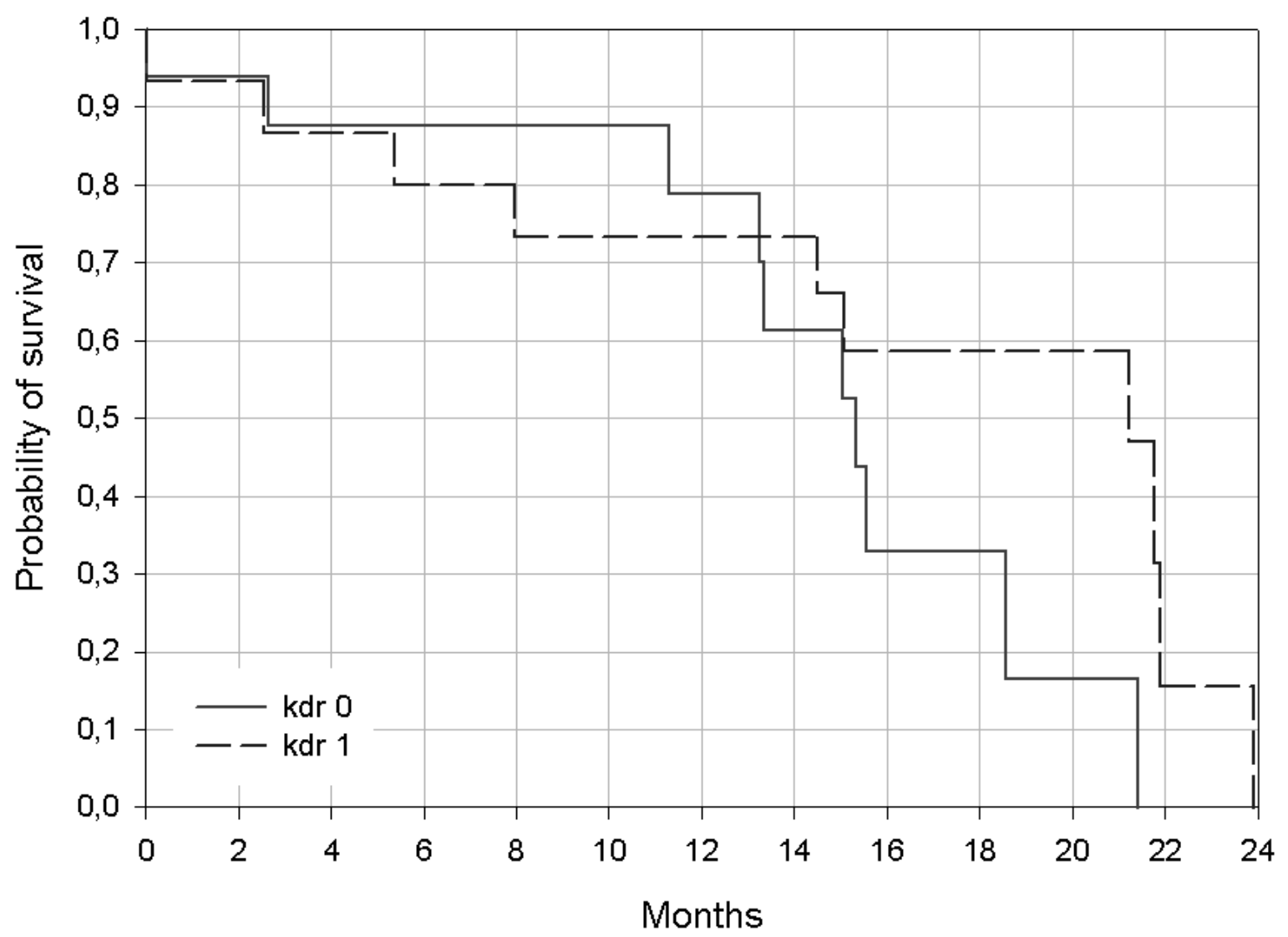




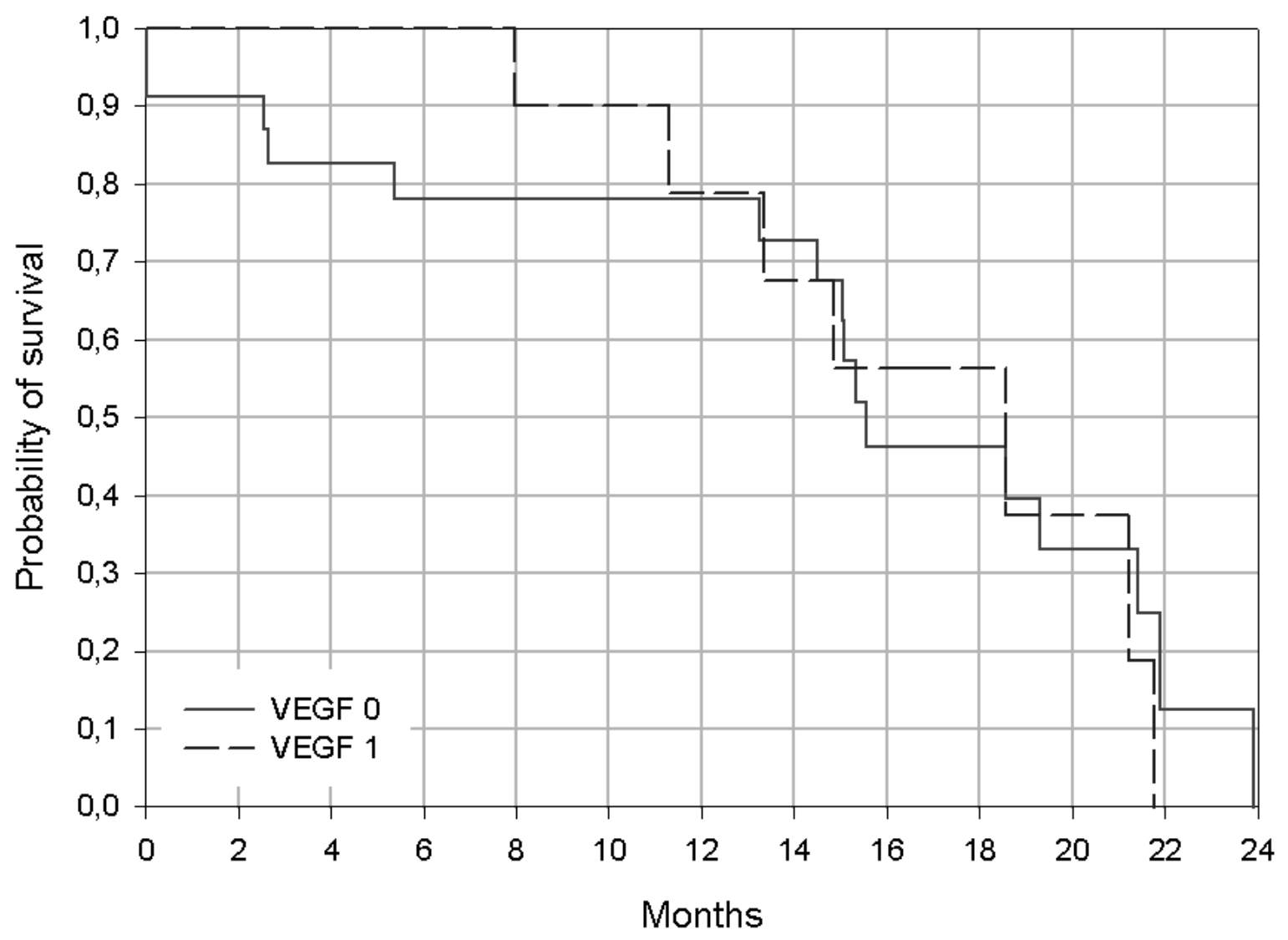

